\title{
1. Introduction: a comparative study of the OECD and European welfare states
}

\section{Michelle Beyeler}

This book is about the internationalisation of ideas concerning the design of national welfare systems. How do ideas develop in international organisations and to what extent and under what conditions are they translated into national policies? We focus on the Organisation for Economic Co-operation and Development (OECD). This international organisation is well suited for our purpose, because it can neither exert regulatory nor financial pressure to influence the behaviour of national actors. If the OECD wants to influence national policies, it has to persuade national actors of the solutions it provides to cope with domestic economic problems. One method by which the OECD presents these solutions to national actors is the regular country surveys issued for all member states. The organisation uses the surveys as a means of pushing their agenda for policy debates and reforms in member countries (cf. Marcussen in this volume).

Two major questions about the interaction of the OECD and domestic systems guide this research. First, we are interested in the consistency of OECD recommendations. Do the ideas and suggestions about welfare state development vary according to the national contexts, or is the OECD promoting uniform best practices for all countries? Second, we analyse the effectiveness of the recommendations. To what extent are actual policy developments in a country in concordance with the OECD policy recommendations? When and why does concordance not occur? Rather than expecting OECD ideas to have a direct and uniform impact on national welfare states, we hypothesise that the impact depends on the fit of national institutions, policies and politics as well as other external pressures - for instance, Europeanisation.

Our aim is to describe and analyse the development of OECD ideas concerning national social policies, and to assess their possible impact on national welfare reforms. This is done by highlighting the problems, criticisms and recommendations the organisation puts forward in its periodical country surveys and contrasting them with the reforms actually realised in 14 Western European welfare states. This procedure allows for systematic descriptive longitudinal and comparative analyses. We are aware of the difficulties in measuring ideational impact. Thus, our objective in this respect is modest: we 
want to give an impression of the extent to which ideas put forward by the OECD could have been received and accepted by national governments.

This introduction is divided into five sections. The first two sections briefly introduce the literature on globalisation and welfare state change, as well as touching on the different conceptualisations of the relationship between ideas and public policy. Based on these accounts, we have developed a framework of analysis which acts as a guide for our study. This framework of analysis is discussed in the third section. Our principal research methods are presented in the fourth section. The introductory chapter concludes by describing the plan of this book.

\section{GLOBALISATION AND WELFARE STATE CHANGE}

According to Schmidt (2001), globalisation can be defined as a set of international economic, institutional and ideational forces for change affecting national policies, practices and politics. Systematic comparative research on welfare state reform, so far, has often focused on the first two types of external forces which result in change: increasing economic integration, and international regulation. A large body of literature discusses the effect of economic integration (both global and European) on welfare states (e.g. EspingAndersen 1996; Huber and Stephens 2001; Rhodes 1995; Scharpf and Schmidt 2000).

Originally the argument was that high levels of capital mobility, and an international coordinated deregulation of markets (negative integration) both increase competition between welfare regimes and trigger a 'race to the bottom', leading to welfare retrenchment in countries with high levels of social security spending (Strange 1988). Positive integration - i.e. common international regulation - is seen as the recipe for preventing such competitive deregulation. However, positive integration because of the intergovernmental mode of decision making at the international level needs a high level of consensus, which is hardly achievable if governments disagree on the level of social regulation (Scharpf 1996). Jensen (2000) identifies a trend toward increasing integration in the fields of labour market and social policies in the European Union. Still, common European regulation in the field of social policies - except in regard to gender equality and working conditions - remains restricted (Liebfried and Pierson 2000).

\section{The Role of the National Political and Institutional Context}

Two sorts of arguments were put forward to explain why empirical studies found limited direct impact when analysing the effects of international economic and political transformation on domestic welfare states. One points 
to the role of domestic institutional and political reform capabilities as mediating factors between international developments and domestic change, whereas the second argument is based on the concept of path dependency and institutional lock-in.

According to the first argument, the impact of economic globalisation is mediated by the domestic political and institutional context. Political institutions are seen as constraints (veto-points or veto-players), impeding governments from undertaking large reforms, and producing policy stability (Immergut 1992; Schmidt 1996; Tsebelis 2002). The pressures stemming from global transformations are filtered by domestic political institutions and power structures (Garrett and Lange 1995; Huber and Stephens 2001; Keohane and Milner 1996; Scharpf 2000; Schmidt 2001). Furthermore, Europeanisation research holds that the effects of European integration on domestic systems are differential. They are contingent on the domestic institutional, political and economic particularities, as well as on the degree of 'fit' between the required policies and institutions and those already in existence (Börzel and Risse 2000; Cowles et al. 2001).

The institutional lock-in argument is put forward by a tradition of comparative welfare state research treating different national systems of social provision as the products of long periods of institutionalisation (Pierson 2000a). From this perspective, welfare states are seen as stable institutions which develop in a contingent, path-dependent manner. They are not just the outcome of functional demands or power struggles; rather, their development can be traced to a particular series of historical conjunctures. Power distribution can, but does not necessarily have to, correspond systematically to the evolution of institutions. Relatively small events, if they occur at the right moment, may have long and enduring consequences, whereas an event that happened 'too late' may have no impact at all (Pierson 2000a, p. 263).

Esping-Andersen $(1990,1999)$ identifies three welfare regimes which can be traced back to different political configurations. Central to this regimetypology are the different underlying values and ideologies. Liberal welfare states, for instance, emerged in relation to the liberal ideology of market sovereignty and minimal states, while the ideological roots of social democratic welfare states consist of values such as egalitarianism, and those of conservative welfare states are based on Christian values of family and solidarity. These underlying policy paradigms not only explain why welfare states developed in quite distinctive ways, they also contribute to their reform resistance.

\section{IDEAS AND POLICY CHANGE}

Besides the objective, material constraints which are put on welfare states 
through international economic and political integration, there is a third, 'soft' channel through which globalisation may affect national welfare systems: the policy models and ideas promoted by international actors. '[G]lobalization ... can also be thought of as a provider of specific solutions for the problems met by welfare states' (Palier and Sykes 2001, p. 10). It is this facet of globalisation that we are interested in discussing in the remainder of this volume.

Why should we expect ideas to have an impact on welfare reform? The technical answer to this question is that due to the extremely high complexity of the issue and the great uncertainty about future developments, human beings are only capable of calculating limited models of possible policy effects on different social groups. They need simplifications, in the form of models or theories, in order to be able to sufficiently grasp the range of problems and possible solutions (Simon 1955, p. 100). These theories which individuals or communities employ to explain the world around them are subjective perceptions, coloured by normative views of how the world should be organised (North 1990, p. 23). New ideas may trigger policy changes, because they provide alternative 'theories' that are seen to be more appropriate. Most likely, social actors will adjust their perceptions when they believe that their previous views and models have yielded poor policy outcomes. This means that it is the experience of failure which triggers the search for new solutions (or policy models) (Marcussen 1999, p. 388). One could also say that, by means of policy experimentation, ideas bring about welfare reform (Hall 1993; Hemerijck and Schludi 2000). ${ }^{1}$

\section{Epistemic Communities}

The question this book seeks to answer is not whether ideas matter. We are interested in the how. How do international actors shape causal social policy models and when and under what conditions do these ideas affect domestic policies? One way to conceptualise the link between international ideas and domestic policies is to point out the role of policy experts. Take, for example, the role of analysts of epistemic communities (Haas 1992). 'An epistemic community is a network of professionals with recognised expertise and competence in a particular domain and an authoritative claim to policy-relevant knowledge within that domain' (Haas 1992, p. 3). Epistemic communities gain political influence in two ways. First, they affect policy making by diffusing ideas and thereby influencing the positions of a wide range of actors, such as bureaucrats and decision makers, as well as the general public. Second, epistemic community members may acquire bureaucratic positions and exert a direct influence on policy design.

The legitimacy and power of epistemic communities stems from their capacity to process more information, and their ability to present more realistic 
models of the world. But why should policy makers rely on the expertise of the epistemic community? Yee (1996, p. 88) raises this question and points out that politicians often shape the scientific agenda and also use science selectively to legitimate policies chosen by means of other criteria. The strength of the epistemic community approach is the way in which it exposes us to the role of international scientific communities as promoters of common policy models. Its weakness is that it offers little insight into the dynamics of how ideas are translated into domestic policy making.

\section{New Institutionalist Approaches to Ideas and Policy Effects}

New institutional analysis conceptualises such effects in more detail. This approach especially points to the role of political institutions in implementing and consolidating policies based on new ideas. 'Powerful individuals are important for the adoption of ideas, but if these ideas do not find institutional homes, they will not be able to sustain themselves over the long term' (Sikkink 1991, p. 248). Or, to put it even more directly: '[I]deas acquire force, when they find organizational means of expression' (Hall 1986, p. 141). The conceptualisation of institutions in this approach is a key factor in understanding this claim. Institutions are defined as systems of rules that can be both formal, like written norms and procedures, law and contracts, and informal, like norms of behaviour, codes of conduct and conventions (Hall 1986, p. 19; North 1990, p. 30). Institutions embody supra-individual abstract devices and guiding ideas of what the institution does and what can legitimately be expected of it (Edeling 1998, p. 730). Therefore, once policy ideas are institutionalised as guidelines in a system of rules, they become powerful motors of future policy development.

The same mechanism, on the other hand, explains why many policy ideas do not find their way into the actual policy-making process. Implementing a policy based on a new idea means that one has to change one or several aspects of the system of rules constituting an institution. The more the new policy idea challenges the current modes of operation, based on prevailing formal and informal rules, the more difficult it becomes to implement. Institutionalists hold that decisions taken within this system of rules are often not consequential in the sense of a rational calculated reaction to the problem; rather, actors make decisions in a way which is appropriate within their institutionally defined roles (Finnemore and Sikkink 1998; March and Olsen 1989, 1998). Accordingly, the more the new policy ideas fit in with the existing ideas and ideologies, the more chance they have of becoming influential (Hall 1989; Sikkink 1991).

Discourse theories are the most explicit on the mechanisms of ideational transfer to policy action (Yee 1996). Discourse and communicative action are 
seen as important mediators, explaining why certain ideas gain importance in the policy-making process (Risse 2000; Schmidt 2000, 2002).

\section{ANALYSING OECD IDEAS AND EUROPEAN WELFARE STATES}

In this study we are interested in the relationship between ideas stemming from an international organisation - the OECD - and their possible impact on national welfare states in Western Europe in the period from 1970 to 2000 . By 'policy ideas' we mean the OECD's perceptions about the deficiencies, virtues and improvements of welfare institutions and policy instruments. Our focal point is the possible ideational effects on the welfare functions concerning employment, old age, health, education, poverty and social transfers in general.

The analysis is further restricted to 14 OECD member countries in Western Europe. There are two substantial and one practical reason for this selection. On one hand, European welfare states have often been regarded as an identifiable group forming a 'European social model' (Palier and Sykes 2001, p. 2). Therefore the comparability between the different systems is given. On the other hand, variation within this 'social model' allows for the study of different contexts in a controlled setting. The more practical reason for the country sample is that the project originates from a European research initiative and the selection was partly defined by the availability to participate of national social policy experts. Still, we are able to present analyses from countries covering all important welfare varieties in Western Europe: the four Scandinavian countries exemplify different aspects of the Nordic model, which in the Esping-Andersen (1990) typology is classified as social-democratic, characterised by an egalitarian and universalistic approach to social welfare. From the continental welfare states (often classified as conservative or Christian-democratic), we cover France, Belgium, Germany, the Netherlands, Switzerland and the southern European countries of Greece, Italy and Spain. In these welfare systems, the emphasis lies on the social security contributions of employers and employees, rather than on universalistic social provisions. Ireland and the United Kingdom represent the liberal approach, which relies more on private welfare and means-tested state provisions.

How does the OECD address the problems each of these welfare states is confronted with? What aspects of the system are criticised? What recommendations and solutions does the organisation present to different countries? Drawing on the theoretical conceptualisations discussed above regarding the link between ideas and public policy, it is possible to derive two competing hypotheses concerning the kind of ideas we can expect to be addressed 
towards domestic welfare states. The epistemic communities approach tells us that a policy idea becomes powerful if the diffusers are conceived of as actors with expertise and policy-relevant knowledge. This implies that the OECD's analyses, criticisms and subsequent recommendations for problems must follow the criteria of clean, scientific analysis. In addition, there should be coherence in the way the OECD reports on different countries and welfare systems. On the other hand, new institutionalist approaches to the impact of ideas hold that the more compatible an idea is with prevailing values, the more chance it has of becoming influential. The implication of this claim is that the OECD can improve its influence by taking specific national policy cultures and values into account. We should thus be able to see differences in the way in which the OECD interacts with different member countries. For instance, we should be able to observe differences in when, how and why the OECD offers criticism - as well as noting differences in the recommendations given. Our first question guiding the empirical analysis therefore concerns the consistency of the OECD's ideas: are the ideas the same across the board, or do they vary according to the national context?

Our second guiding question refers to the possible impact of OECD ideas on policy development. Are the ideas promoted by the OECD effective in changing domestic policy? Based on the globalisation and Europeanisation literature, as well as on ideational new institutionalist accounts, we can assume that the OECD's ideas will be more effective provided the politico-institutional structure in a country is favourable for the adoption of the recommendations. We expect that the 'fit' of the politico-institutional structure is an important mediating factor on ideational 'pressures'. In addition, the possibility of ideas changing policies also varies with the actual policy design. A necessary condition, for observing a policy change is that the prevailing policy differs from that advocated by the OECD. Ideas will only produce an actual change in policies if they do not 'fit' with the current national policy solution. Based on institutional lock-in arguments and new institutionalist views on ideational impact, we expect that policy development remains within the path that is possible given prevailing institutional legacies and values. Both national varieties of welfare state design, as well as the broader domestic political and institutional context, are thus likely to matter for the effectiveness of OECD ideas.

\section{METHODOLOGICAL ISSUES}

Our research method is qualitative and comparative over time and between countries. For each country we gathered comparative data on the OECD's analyses, criticisms and recommendations in a standardised manner. The 
sources for this content analysis are the summarising chapters of the OECD's Economic Surveys in the period from 1970 to 2000. We extracted the OECD's statements on social expenditure in general or on specific social policies (related to employment, old age, health, education or poverty) according to three criteria: What are considered the major problems in the respective policy fields? What are the major criticisms? What are the major policy recommendations issued? The question of whether the OECD has been consistent over time and between countries can be answered based on these descriptive data.

Assessing the effectiveness of the OECD in changing domestic policies is more complicated. Yee (1996) distinguishes three methodological procedures to measure the effects of ideas on policy: co-variational analysis, the congruence procedure and process tracing. According to proponents of co-variational analysis, ideational effects can be tested if the development of ideas correlates with the development of policies. However, this type of analysis is problematic as soon as we expect the relationship between ideas and policies to be nonlinear, highly contingent on other factors, and differential in relation to the time lags between ideational and policy change. In this case the absence of covariation cannot be interpreted as proof for the absence of a relationship. Process tracing, on the other hand, is a method particularly attentive to the sequences as well as the complex relationships between policies (Hall, forthcoming). The drawback of this method is that it requires the gathering of a large amount of information and is thus quite costly and time-intensive.

Therefore, in this study, we apply the congruence procedure (Yee 1996, pp. 76-77). This research method essentially entails establishing 'congruence' (or concordance) between ideas and the content of policy decisions. If the policy development is consistent with the policy recommendations raised by the OECD, this can be taken as an indication of a possible OECD influence. However, concordance in policy changes and recommendations does not establish 'proof' of the OECD's impact. Perhaps the idea of policy change has been developed on the national level, and was later incorporated into and published as part of the Economic Survey. Or the need for reform has been felt on the national level and the solution to the problem has been developed by national actors like politicians or administrative elites quite independently of the arguments of the international organisation. If there is discordance, i.e., the national policy development does not follow the OECD's recommendations, or even goes in the opposite direction, we can consider this an example of a situation where the OECD lacks efficacy in influencing national policy. Still, it is not proof of a complete absence of impact, since the national policy might have been even more radical had it not been for the tempering influence of the OECD's proposal.

One major problem with the method employed is that the ideas promoted by the OECD are not exclusive to the organisation. The same or largely similar 
ideas can also stem from other international or domestic sources. By searching for instances where actors make a clear reference to the OECD during a discourse on reform, we attempt to further validate our assessment of the organisation's impact. In most countries, as well as in the different policy fields under study, a limited number of significant policy changes occurred. If during such reform debates national actors explicitly refer to OECD recommendations, we consider this an indicator of influence. Of course, national actors can adopt these arguments on purely strategic reasons or actors may adopt the OECD ideas without quoting the OECD. Thus, these cases do not produce unequivocal evidence. They hint, however, at the direct impact the OECD can have on national policy discourse.

Although we are sensitive to the criticism that with this frame of analysis we cannot establish conclusive proof of the OECD's relevance or non-relevance, we still consider our study a valid means of assessing the effectiveness of the organisation. Even if we had conducted in-depth case analyses, for instance with semi-structured interviews, it would be difficult to pin down the effective impact of the ideas. Our frame of analysis has the advantage over other research strategies that it generates comparable data based on clear criteria.

\section{PLAN OF THE BOOK}

In the next chapter Martin Marcussen presents the view from within the OECD. He argues that the organisation has established a form of multilateral surveillance based on moral pressure and soft regulation. The contribution contains both a description of how this type of multilateral surveillance works, as well as a conceptual framework to characterise the various roles the OECD plays in this process.

Chapters 3 to 16 are devoted to the country studies. Each chapter starts with a short description of the political institutional context and the historical roots of the respective welfare system. In the second part, the authors present a table covering the main social policy issues (recognition of problems, criticisms and recommendations) raised in the OECD country surveys. Then they contrast the recommendations given by the OECD with the actual policy development. The country experts assess whether there had been concordance or discordance between recommendations and policy reforms, and whether the OECD's ideas had been explicitly addressed in the national policy discourse.

The book concludes with a comparative account. Klaus Armingeon systematically compiles the findings from the country chapters in order to evaluate the two guiding questions regarding the consistency and effectiveness of OECD ideas. He comes to the conclusion that OECD recommendations have been highly consistent between countries and also over time - if one takes into 
account a clearly visible shift from demand-oriented policies in the early 1970s to supply-oriented ones thereafter. It is, however, this consistency in policy ideas which often inhibits the reflection of OECD recommendations in concrete policy developments at the national level. Only when the OECD comes up with proposals that correspond with national policies, institutions and broadly held values is there likely to be meaningful policy development. Otherwise, national political opposition and institutional inertia inhibit a clear and direct effect.

\section{NOTE}

1. Note that social learning in this definition does not contain a normative judgement on the quality of the theories before and after the 'learning' process. Social learning can be a means of adding new information and thus of introducing more complexity into one's perception of the world, but it does not always have that effect. There is also the possibility that the old perceptions are given up entirely, and that the new model is seen as the appropriate one in the future - if the amount of information processed in each model remains the same, then there is no guarantee that the second model is more realistic than the first.

\section{REFERENCES}

Börzel, Tanja A. and Thomas Risse (2000), 'When Europe hits home: Europeanization and domestic change', European Integration Online Papers 4 (15), $<$ http://eiop.or.at/eiop/texte/2000-015a.htm>.

Cowles, Maria Green, James Caporaso and Thomas Risse (eds) (2001), Transforming Europe. Europeanization and Domestic Change, Ithaca, NY and London: Cornell University Press.

Edeling, Thomas (1998), 'Economic and sociological institutionalism in organization theory: two sides of the same coin?' Journal of Institutional and Theoretical Economics 154 (4), 728-734.

Esping-Andersen, Gøsta (1990), The Three Worlds of Welfare Capitalism, Princeton: Princeton University Press.

Esping-Andersen, Gøsta (ed.) (1996), Welfare States in Transition. National Adaptations to Global Economies, London: Sage.

Esping-Andersen, Gøsta (1999), Social Foundations of Postindustrial Economies, New York: Oxford University Press.

Finnemore, Martha and Kathryn Sikkink (1998), 'International norm dynamics and political change', International Organization 52 (4), 887-917.

Garrett, Geoffrey and Peter Lange (1995), 'Internationalization, institutions, and political change', International Organization 49 (4), 627-655.

Haas, Peter M. (1992), 'Introduction: epistemic communities and international policy coordination', International Organization 46 (1), 1-35.

Hall, Peter A. (1986), Governing the Economy. The Politics of State Intervention in Britain and France, New York and Oxford: Oxford University Press.

Hall, Peter A. (1989), 'Conclusion: the politics of Keynesian ideas', in Peter A. Hall (ed.), The Political Power of Economic Ideas. Keynesianism across Nations, Princeton, NJ: Princeton University Press, pp. 361-391. 
Hall, Peter A. (1993), 'Policy paradigms, social learning, and the state, the case of economic policymaking in Britain', Comparative Politics 25 (3), 275-296.

Hall, Peter A. (forthcoming), 'Aligning ontology and methodology in comparative research', in James Mahoney and Dietrich Rueschemeyer (eds), Comparative Historical Analysis in the Social Sciences, Cambridge: Cambridge University Press.

Hemerijck, Anton and Martin Schludi (2000), 'Sequences of policy failures and effective policy responses', in Fritz W. Scharpf and Vivien A. Schmidt (eds), Welfare and Work in the Open Economy, Volume I, From Vulnerability to Competitiveness, Oxford: Oxford University Press, pp. 125-228.

Huber, Evelyne and John D. Stephens (2001), Development and Crisis of the Welfare State. Parties and Policies in Global Markets, Chicago and London: University of Chicago Press.

Immergut, Ellen M. (1992), Health Policies. Interests and Institutions in Western Europe, Cambridge: Cambridge University Press.

Jensen, Carsten S. (2000), 'Neofunctionalist theories and the development of European social and labour market policy', Journal of Common Market Studies 38 (1), 71-92.

Keohane, Robert O. and Helen V. Milner (eds) (1996), Internationalization and Domestic Politics, Cambridge: Cambridge University Press.

Liebfried, Stephan and Paul Pierson (2000), 'Social policy. Left to courts and markets?' in Helen Wallace and W. Wallace (eds), Policy-Making in the European Union, Oxford: Oxford University Press, pp. 267-292.

March, James G. and Johan P. Olsen (1989), Rediscovering Institutions. The Organizational Basis of Politics, London: Macmillan.

March, James G. and Johan P. Olsen (1998), 'The institutional dynamics of international political orders', International Organization 52 (4), 943-969.

Marcussen, Martin (1999), 'The dynamics of EMU-ideas', Cooperation and Conflict 34 (4), 383-411.

North, Douglass C. (1990), Institutions, Institutional Change and Economic Performance, Cambridge: Cambridge University Press.

Palier, Bruno and Robert Sykes (2001), 'Challenges and change: issues and perspectives in the analysis of globalization and the European welfare states', in Robert Sykes, Bruno Palier and Pauline M. Prior (eds), Globalization and European Welfare States, Basingstoke: Palgrave, pp. 1-16.

Pierson, Paul (2000a), 'Three worlds of welfare state research', Comparative Political Studies 33 (6/7), 791-821.

Pierson, Paul (2000b), 'Increasing returns, path dependence, and the study of politics', American Political Science Review 94 (2), 251-267.

Rhodes, Martin (1995), 'Subversive liberalism: market integration, globalization and the European welfare state', Journal of European Public Policy 2 (3), 384-406.

Risse, Thomas (2000), 'Let's argue!: communicative action in world politics', International Organization 54 (1), 1-39.

Scharpf, Fritz W. (1996), 'Negative and positive integration in the political economy of European welfare states', in Gary Marks, Fritz W. Scharpf et al. (eds) Governance of the European Union, Thousand Oaks, CA and New Delhi: Sage, pp. 15-39.

Scharpf, Fritz W. (2000), 'Economic changes, vulnerabilities, and institutional capabilities', in Fritz W. Scharpf and Vivien A. Schmidt (eds) Welfare and Work in the Open Economy, Volume I, From Vulnerability to Competitiveness, Oxford: Oxford University Press, pp. 21-124.

Scharpf, Fritz W. and Vivien A. Schmidt (eds) (2000), Welfare and Work in the Open Economy, Volume I and II, Oxford: Oxford University Press. 
Schmidt, Manfred G. (1996), 'When parties matter: a review of the possibilities and limits of partisan influence on public policy', European Journal of Political Research 30 (2), 155-183.

Schmidt, Vivien A. (2000), 'Values and discourse in the politics of adjustment', in Fritz W. Scharpf and Vivien A. Schmidt (eds), Welfare and Work in the Open Economy, Volume I, From Vulnerability to Competitiveness, Oxford: Oxford University Press, pp. 229-309.

Schmidt, Vivien A. (2001), 'Europeanization and the mechanics of economic policy adjustment', European Integration online Papers (EIoP) 5(6), <http://eiop.or.at/ eiop/texte/2001-006.htm>.

Schmidt, Vivien A. (2002), The Futures of European Capitalism, Oxford and New York: Oxford University Press.

Sikkink, Kathryn (1991), Ideas and Institutions. Developmentalism in Brazil and Argentina, Ithaca, NY and London: Cornell University Press.

Simon, Herbert A. (1955), 'A behavioral model of rational choice', Quarterly Journal of Economics 69 (1), 99-118.

Strange, Susan (1988), States and Markets, London: Pinter.

Tsebelis, Georg (2002), Veto Players. How Political Institutions Work, Princeton, NJ: Princeton University Press.

Yee, Albert S. (1996), 'The causal effects of ideas on policies', International Organization 50 (1), 69-108. 